\title{
Empirical Analysis of Demographic Factors Affecting Intention to use Mobile Wallet
}

\author{
S.Vasantha, P. Sarika
}

\begin{abstract}
Purpose: Development of digitalisation in banking services brought changes in the minds of customers to adopt different e -channels of banking products and services. Adoption of mobile wallet may be influenced by the demographic variables of customers. The study aims to understand the influence of demographic variables on the factors of intention to use mobile wallets
\end{abstract}

\section{Methodology/ Approach}

Primary and Secondary data have been utilized for analysis. The sample size of 200 respondents are chosen on method of judgement sampling

Novelty

Mobile wallet is one of the robust methods of making payments through online which is tremendously increased gain importance in the digital era among millennials generation group. Limited research has been conducted in the area of mobile wallet adoption. The proposed research work adds new dimension to the existing research work that the role of demographic variables on the usage of mobile wallet

Practical Implications

The outcomes of the current study would help the government for formulating polices and taking strategic decisions. Further the research would add value addition to mobile wallet service providers to devise strategies that will foster the mobile wallets' adoption by the end users.

\section{Findings}

It has been found that with respect to genders, the factor personal innovativeness makes significant difference on the intent to use mobile wallet and the other factors such as perceived enjoyment and subjective norms do not differ significantly. Age has a significant difference on the mobile wallet usage intention.

Keywords: Demographic variables, Mobile wallet, Intention to use, perceived enjoyment Personal Innovativeness, Subjective Norms.

\section{INTRODUCTION}

In present digital era the growth of smart phone users and increased usage of internet facilities influenced the adoption of mobile wallet. The Government revolutionary steps on demonetization made the public to shift from cash transaction to cashless transaction

The research conducted by research firm RNCOS reveals that the present Indian mobile wallet market share is nearly Rs. 350 crore .It is estimated that by the end of the year 2019

Revised Manuscript Received on July 22, 2019.

Dr. S.Vasantha, Professor, School of Management Studies, Vels Institute Of Science Technology \& Advanced Studies (VISTAS)

P. Sarika, Ph.D Research Scholar, School of Management Studies, Vels Institute of Science Technology and Advanced Studies (VISTAS) the mobile wallet market share is Rs. 1210 crore. Considering the present situation in India and digital India initiatives of Government definitely push the adoption of mobile wallet in the coming years

According to RBI 's provisional data Digital transactions in December 2017 cross over the 1 Billion Mark, moving a new peak in terms of volume since the government's exercise on demonetization in November 2016. Transactions through the Unified Payment Interface (UPI) also touched a new high, clocking 145.5 million transactions in December 2017.The research report of Google and the Boston Consulting Group in September 2016, states that by the year 2020 digital payments industry will raise 10 times which will contribute to $15 \%$ of GDP

Based on TAM model and its extension most of the researchers concluded that, the factors determine the usage of online banking are perceived use, perceived ease of use, perceived security, perceived speed, Personal Innovativeness, Subjective Norms and perceived enjoyment.

\subsection{Personal Innovativeness in Technology}

Personal Innovativeness in Technology states that an individual uses the technology at the stage of the implementation of new technology itself and thereby the individual proves to be an initial stage adopter. Thus it can be concluded that preliminary stage adopters are the individuals with higher technical skills and capability. Therefore, it can be stated that the technology will be relaxed for the preliminary stage adopters of technology when compared with the individuals who are late adopters.

\subsection{Perceived Enjoyment}

Perceived Enjoyment is the extent to which the user perceives the experience of utilization of a particular system to be enjoyable. This does not take into consideration the consequences of performance related to the system.The enjoyment on adoption of technology is established through consumers' existing experience. The enjoyment of the information system is as relevant to its usability and utility.

\subsection{Social Influence}

Social influence is the perceived influence of important others who inspire consumers in the usage of the technology in the transaction. The Relevant Others can be the families, couples and organizations. Social influence is the perception of relevant people who enforce on adoption. Previous research explained that the voice of important others causes personal intention to use a new technology.

\section{OBJECTIVE OF STUDY}

The study aims to analyze the

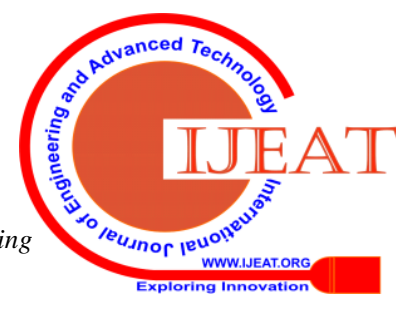




\section{Empirical Analysis of Demographic Factors Affecting Intention to use Mobile Wallet}

effect of demographic variables, Gender and Age, on the factors that motivate the users' intent of mobile wallet adoption.

\section{LITERATURE REVIEW}

Demographic and socio- economic variables have an effect on the mobile wallet adoption. Jham (2005) stated that younger users are more motivated to use online transaction when compared to older consumers. The research conducted by Zeithaml and Gilly (1987), Parasuraman et.al.(1 988)). Shows that the younger age group is more likely adopt e -banking channels than older people and it is also observed that married customers are more likely to use e banking than unmarried. Furnell (2004) stated that customers are more concerned about the confidentiality about their accounts and are worried about the safety measures undertaken by the banks regarding the transactions performed by them. Most of the researchers used modified version of TAM model to ascertain the factors influencing the usage of mobile wallet. Earlier empirical research concluded there is a positive correlation between the critical factors, perceived ease of use and perceived usefulness. They play a crucial role in the intent to adopt mobile banking.(Agarwal et.al. (2000), Johnson and Marakas (2000)). It is observed that chances of using mobile banking by men are more than women [Laukkanen \& Pasanen 2008; Koenig-Lewis 2010], and men are more worried about cost than women[Cruz et al. 2010].

\subsection{Review Mapping}

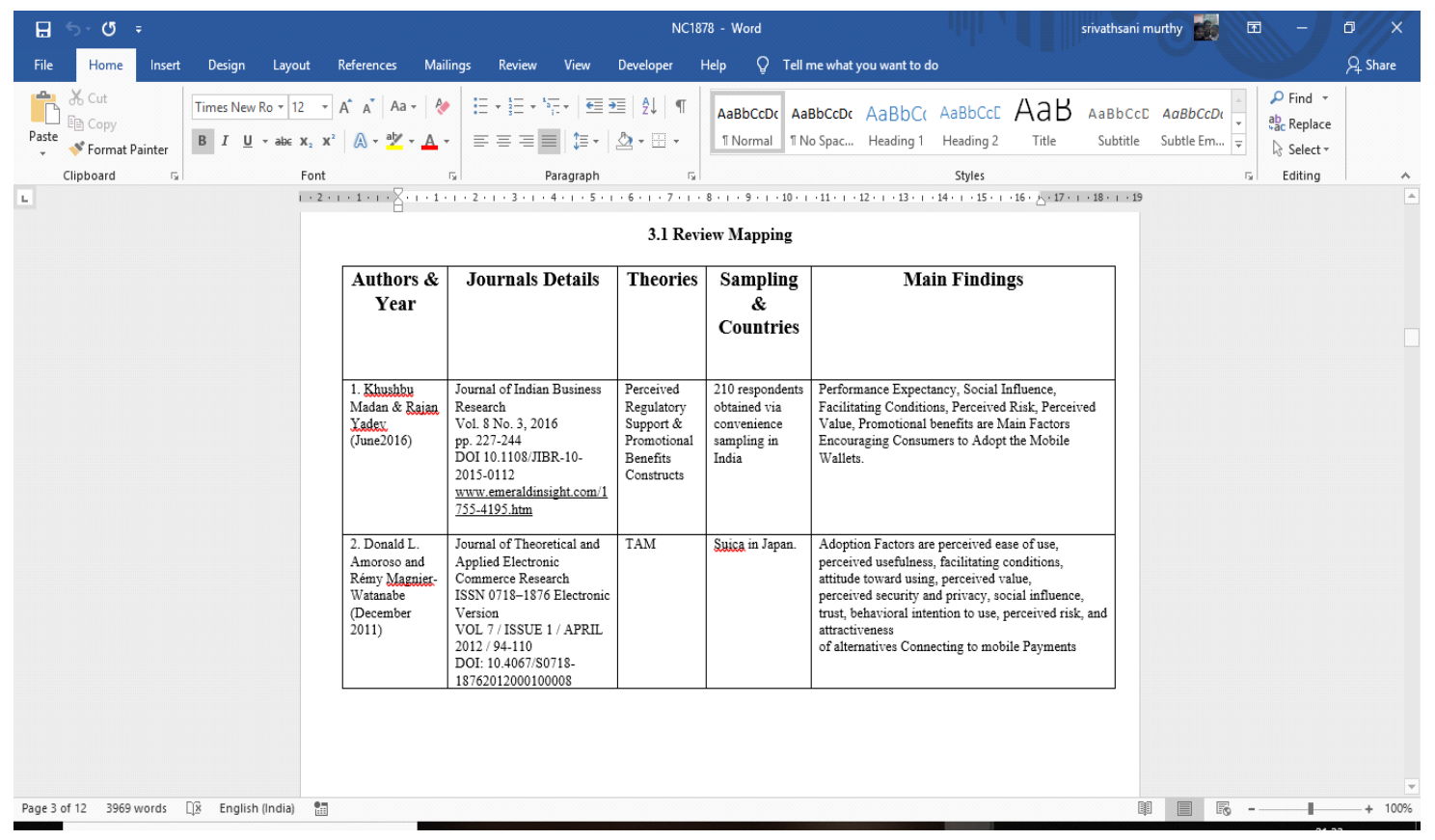




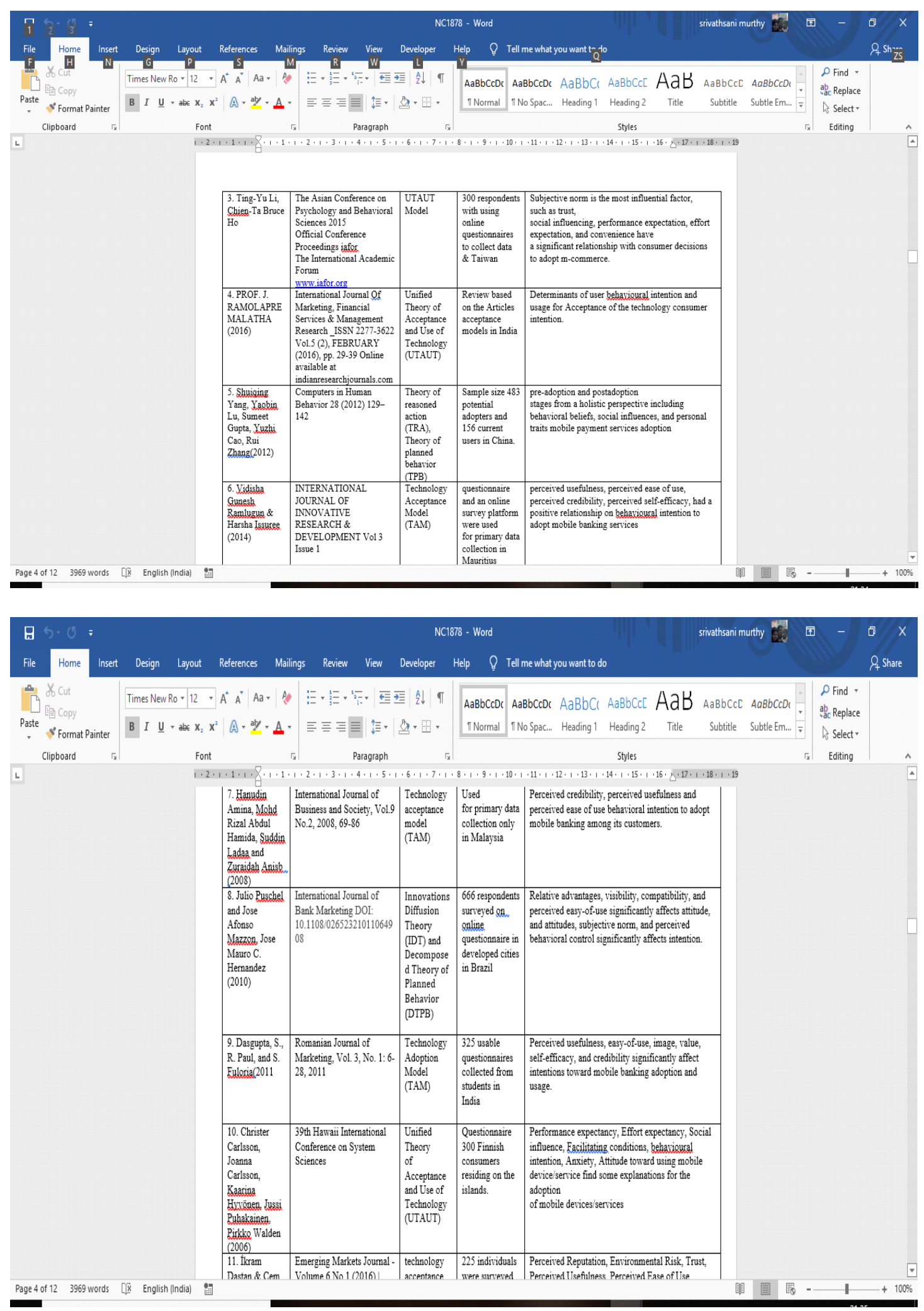


Empirical Analysis of Demographic Factors Affecting Intention to use Mobile Wallet

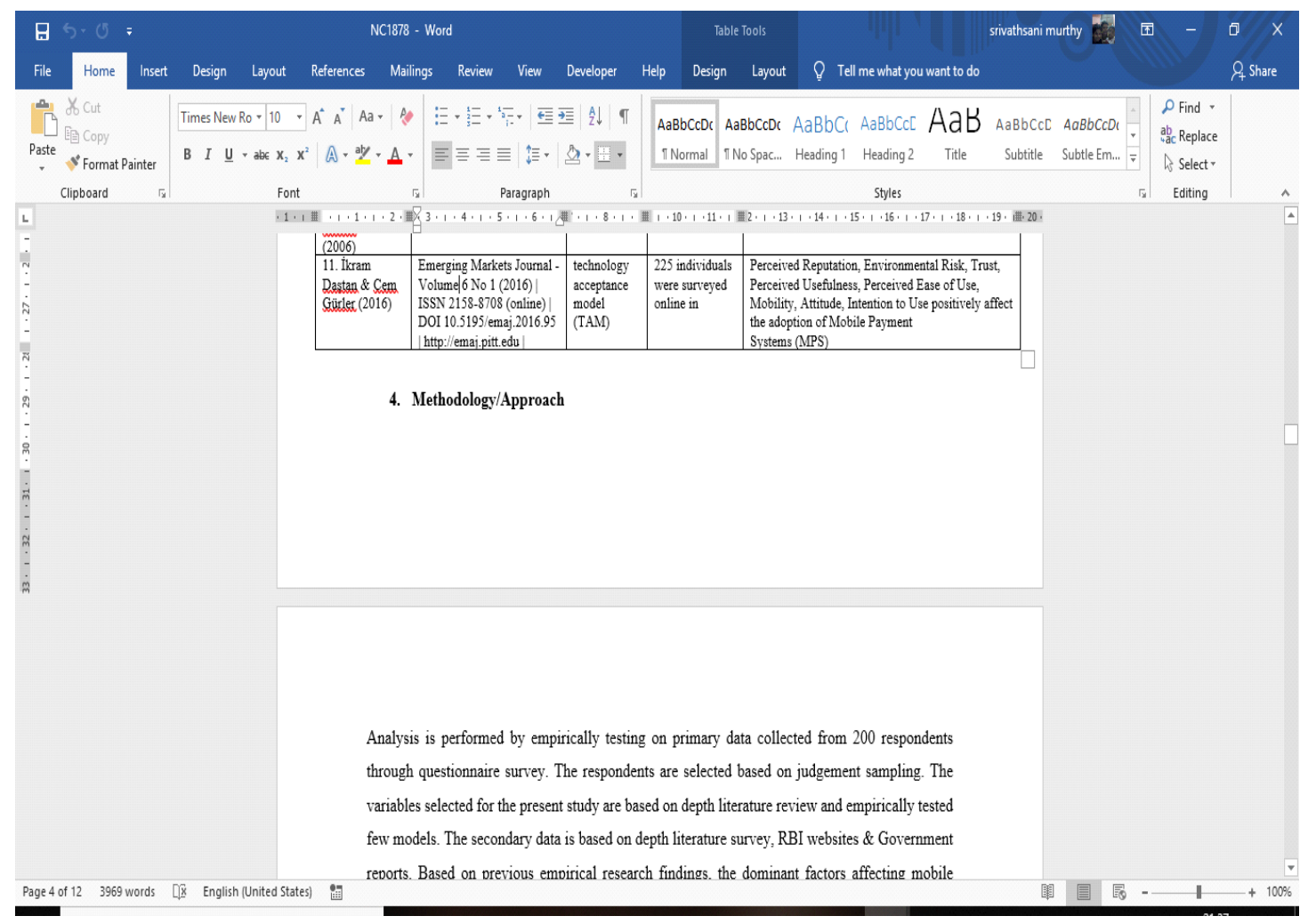

\section{METHODOLOGY/APPROACH}

Analysis is performed by empirically testing on primary data collected from 200 respondents through questionnaire survey. The respondents are selected based on judgement sampling. The variables selected for the present study are based on depth literature review and empirically tested few models. The secondary data is based on depth literature survey, RBI websites \& Government reports. Based on previous empirical research findings, the dominant factors affecting mobile wallet usage are namely Personal Innovativeness, Subjective Norms and perceived enjoyment .

These factors are considered to observe the association among different demographic variables and the intent to use mobile wallet.

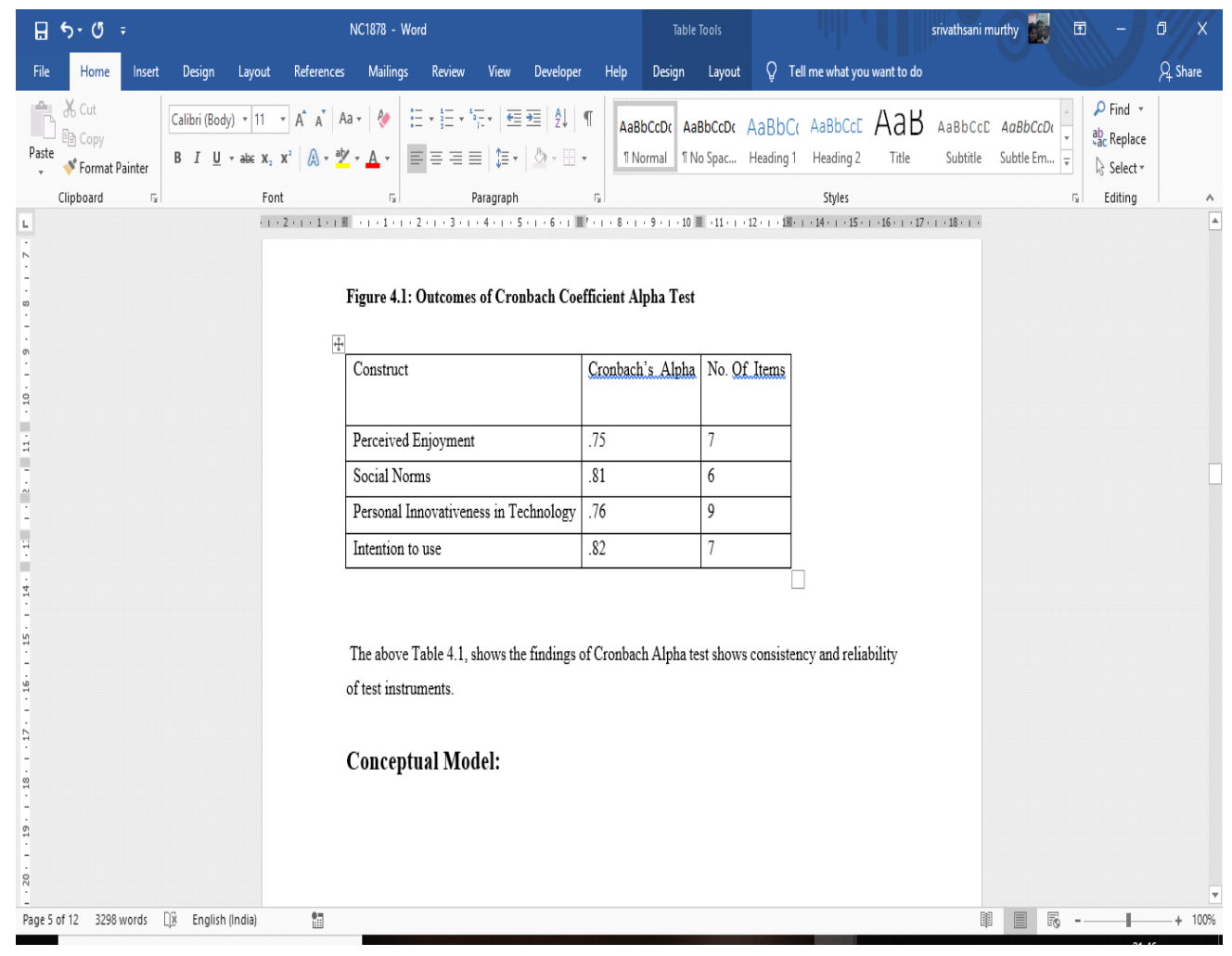


Figure 4.1: Outcomes of Cronbach Coefficient Alpha Test

The above Figure 4.1, shows the findings of Cronbach Alpha test shows consistency and reliability of test instruments.

\section{Conceptual Model:}

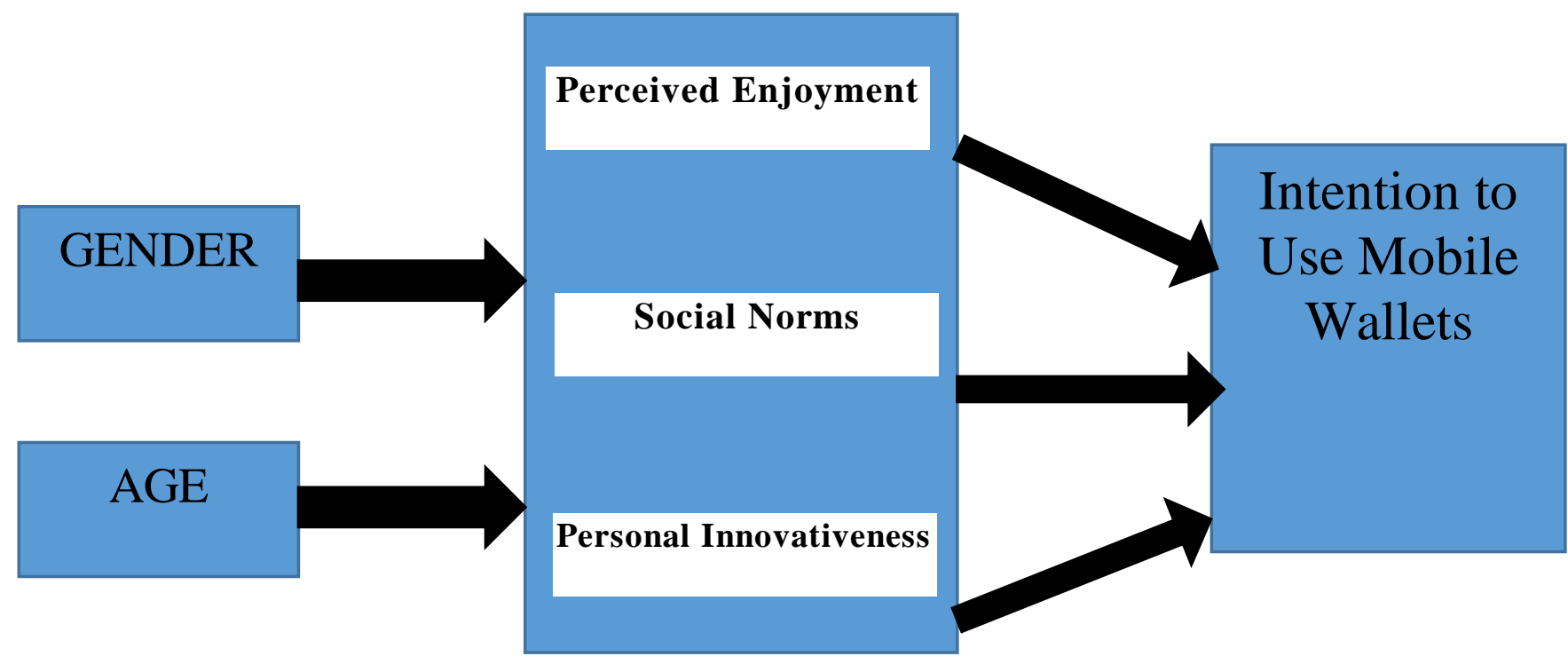

\section{RESULTS \& DISCUSSION}

Null Hypothesis: There is no significant difference between Male \& Female with respect to factors of intention to use mobile wallet

Figure:5. 1 t test to Analysis the significant difference between Male \& Female taking the factors influencing the usage of mobile wallet into account

\begin{tabular}{|l|l|l|l|l|l|l|l|}
\hline \multirow{2}{*}{ Factors } & \multicolumn{3}{|l|}{ Gender } & \multirow{2}{*}{} & \multirow{2}{*}{} \\
\cline { 2 - 5 } & \multicolumn{2}{|l|}{ Male } & \multicolumn{2}{|l|}{ Female } & \multirow{2}{*}{ t value } & P value \\
\cline { 2 - 6 } & Mean & S.D & Mean & S.D & 1.987 & .047 \\
\hline $\begin{array}{l}\text { Personal } \\
\text { Innovativeness }\end{array}$ & 3.68 & 0.66 & 3.79 & 0.69 & 1.00 & .320 \\
\hline $\begin{array}{l}\text { Subjective } \\
\text { Norms }\end{array}$ & 3.69 & 0.72 & 3.75 & 0.82 & 1.00 & .535 \\
\hline $\begin{array}{l}\text { Perceived } \\
\text { Enjoyment }\end{array}$ & 3.75 & 0.72 & 3.79 & 0.78 & 0.62 & \\
\hline
\end{tabular}




\section{Empirical Analysis of Demographic Factors Affecting Intention to use Mobile Wallet}

From the above figure, it is clear that the there is no significant difference exist between male and female with respect to factors of Subjective Norms and Perceived Enjoyment on the intent to use mobile wallet. As the $\mathrm{P}$ value is greater than 0.05 , the null hypothesis is accepted. So, it is inferred that there is no significant difference between Male \& Female taking the factors of Subjective Norms and Perceived Enjoyment into consideration.
With respect to personal innovativeness the $\mathrm{P}$ value is less than 0.05 , the null hypothesis is not accepted. So, there is a significant difference between the two genders when the factor of Personal Innovativeness is considered.

Null Hypothesis $\left(\mathrm{H}_{01}\right)$ : There is no significant difference among Age groups in years with respect to factors of intention to use Mobile wallet.

Table5.1. ANOVA significant difference among Age groups in years taking the factors influencing the usage of mobile wallet into account

\begin{tabular}{|c|c|c|c|c|c|c|}
\hline \multicolumn{7}{|l|}{ ANOVA } \\
\hline & & $\begin{array}{l}\text { Sum of } \\
\text { Squares }\end{array}$ & df & $\begin{array}{l}\text { Mean } \\
\text { Square }\end{array}$ & $\mathrm{F}$ & Sig. \\
\hline \multirow[t]{3}{*}{ subjective norms } & Between Groups & 37.563 & 4 & 9.391 & 17.687 & .000 \\
\hline & Within Groups & 336.623 & 634 & .531 & & \\
\hline & Total & 374.186 & 638 & & & \\
\hline \multirow{3}{*}{$\begin{array}{l}\text { personal } \\
\text { innovativeness }\end{array}$} & Between Groups & 32.328 & 4 & 8.082 & 19.904 & .000 \\
\hline & Within Groups & 257.434 & 634 & .406 & & \\
\hline & Total & 289.762 & 638 & & & \\
\hline \multirow[t]{3}{*}{ perceived enjoyment } & Between Groups & 28.415 & 4 & 7.104 & 13.632 & .000 \\
\hline & Within Groups & 330.374 & 634 & .521 & & \\
\hline & Total & 358.789 & 638 & & & \\
\hline
\end{tabular}

* denotes significant at $5 \%$ level

As $\mathrm{p}<0.01$, the null hypothesis is rejected at 5 percent level of significance. So, there is significant difference between age groups when the factors influencing intention to use mobile wallet namely Subjective Norms, Personal innovativeness and
Perceived Enjoyment are considered.

Null Hypothesis (H02): There is no significant difference among Age groups and factors influencing intention to use mobile wallet.

Figure 5.3 - Multiple comparison - Age VS factors of Mobile wallet Adaptation

\begin{tabular}{|c|c|c|c|c|c|}
\hline \multicolumn{6}{|c|}{ Multiple Comparisons } \\
\hline LSD & & & & & \\
\hline \multicolumn{3}{|c|}{ Dependent Variable } & $\begin{array}{l}\text { Mean Difference } \\
\text { (I-J) }\end{array}$ & Std. Error & Sig. \\
\hline \multirow[t]{5}{*}{ subjective norms } & \multirow[t]{4}{*}{ 20-29 years } & $30-39$ yrs & -.03967 & .07429 & .594 \\
\hline & & $40-49$ yrs & -.05379 & .09305 & .563 \\
\hline & & $50-59 \mathrm{yrs}$ & $-.47491^{*}$ & .08933 & .000 \\
\hline & & 60and above & $.50489^{*}$ & .10804 & .000 \\
\hline & 30-39 years & $20-29$ yrs & .03967 & .07429 & .594 \\
\hline
\end{tabular}




\begin{tabular}{|c|c|c|c|c|c|}
\hline & & $40-49$ yrs & -.01411 & .09236 & .879 \\
\hline & & $50-59$ yrs & $-.43524^{*}$ & .08860 & .000 \\
\hline & & 60and above & $.54457^{*}$ & .10744 & .000 \\
\hline & 40-49 years & $20-29$ yrs & .05379 & .09305 & .563 \\
\hline & & $30-39$ yrs & .01411 & .09236 & .879 \\
\hline & & $50-59$ yrs & $-.42112^{*}$ & .10483 & .000 \\
\hline & & 60and above & $.55868^{*}$ & .12118 & .000 \\
\hline & $50-59$ years & $20-29$ yrs & $.47491^{*}$ & .08933 & .000 \\
\hline & & $30-39$ yrs & $.43524^{*}$ & .08860 & .000 \\
\hline & & $40-49$ yrs & $.42112^{*}$ & .10483 & .000 \\
\hline & & 60and above & $.97981^{*}$ & .11834 & .000 \\
\hline & 60and above & $20-29$ yrs & $-.50489^{*}$ & .10804 & .000 \\
\hline & & $30-39$ yrs & $-.54457^{*}$ & .10744 & .000 \\
\hline & & $40-49$ yrs & $-.55868^{*}$ & .12118 & .000 \\
\hline & & $50-59$ yrs & $-.97981^{*}$ & .11834 & .000 \\
\hline personal & 20-29 years & $30-39$ yrs & .01306 & .06497 & .841 \\
\hline innovativeness & & $40-49$ yrs & $-.16986^{*}$ & .08137 & .037 \\
\hline & & $50-59$ yrs & $-.59639^{*}$ & .07812 & .000 \\
\hline & & 60and above & .08915 & .09448 & .346 \\
\hline & $30-39$ years & $20-29$ yrs & -.01306 & .06497 & .841 \\
\hline & & $40-49$ yrs & $-.18292^{*}$ & .08077 & .024 \\
\hline & & $50-59$ yrs & $-.60944^{*}$ & .07748 & .000 \\
\hline & & 60and above & .07609 & .09396 & .418 \\
\hline & $40-49$ years & $20-29$ yrs & $.16986^{*}$ & .08137 & .037 \\
\hline & & $30-39$ yrs & $.18292^{*}$ & .08077 & .024 \\
\hline & & $50-59$ yrs & $-.42652^{*}$ & .09167 & .000 \\
\hline & & 60and above & $.25901^{*}$ & .10597 & .015 \\
\hline & $50-59$ years & $20-29$ yrs & $.59639^{*}$ & .07812 & .000 \\
\hline & & $30-39$ yrs & $.60944^{*}$ & .07748 & .000 \\
\hline & & $40-49$ yrs & $.42652^{*}$ & .09167 & .000 \\
\hline & & 60and above & $.68553^{*}$ & .10349 & .000 \\
\hline & 60and above & $20-29$ yrs & -.08915 & .09448 & .346 \\
\hline & & $30-39$ yrs & -.07609 & .09396 & .418 \\
\hline & & $40-49$ yrs & $-.25901^{*}$ & .10597 & .015 \\
\hline & & $50-59$ yrs & $-.68553^{*}$ & .10349 & .000 \\
\hline perceived & 20-29 years & $30-39$ yrs & .03615 & .07360 & .624 \\
\hline
\end{tabular}




\section{Empirical Analysis of Demographic Factors Affecting Intention to use Mobile Wallet}

\begin{tabular}{|c|c|c|c|c|c|}
\hline \multirow[t]{19}{*}{ enjoyment } & & $40-49$ yrs & $-.23365^{*}$ & .09219 & .011 \\
\hline & & $50-59$ yrs & $-.45676^{*}$ & .08849 & .000 \\
\hline & & 60and above & $.28191^{*}$ & .10704 & .009 \\
\hline & \multirow[t]{4}{*}{$30-39$ years } & $20-29 \mathrm{yrs}$ & -.03615 & .07360 & .624 \\
\hline & & $40-49$ yrs & $-.26980^{*}$ & .09150 & .003 \\
\hline & & $50-59$ yrs & $-.49290^{*}$ & .08777 & .000 \\
\hline & & 60and above & $.24577^{*}$ & .10644 & .021 \\
\hline & \multirow[t]{4}{*}{$40-49$ years } & $20-29 \mathrm{yrs}$ & $.23365^{*}$ & .09219 & .011 \\
\hline & & $30-39$ yrs & $.26980^{*}$ & .09150 & .003 \\
\hline & & $50-59$ yrs & $-.22311^{*}$ & 10385 & .032 \\
\hline & & 60and above & $.51557^{*}$ & .12005 & .000 \\
\hline & \multirow[t]{4}{*}{$50-59$ years } & $20-29 \mathrm{yrs}$ & $.45676^{*}$ & .08849 & .000 \\
\hline & & $30-39$ yrs & $.49290^{*}$ & .08777 & .000 \\
\hline & & $40-49$ yrs & $.22311^{*}$ & .10385 & .032 \\
\hline & & 60and above & $.73867^{*}$ & .11724 & .000 \\
\hline & \multirow[t]{4}{*}{ 60and above } & $20-29 \mathrm{yrs}$ & $-.28191^{*}$ & .10704 & .009 \\
\hline & & $30-39$ yrs & $-.24577^{*}$ & .10644 & .021 \\
\hline & & $40-49$ yrs & $-.51557^{*}$ & .12005 & .000 \\
\hline & & $50-59$ yrs & $-.73867^{*}$ & .11724 & .000 \\
\hline
\end{tabular}

To analyse the significance difference among different age groups considering the factors of intention to use mobile wallet, LSD was done. The multiple comparison analysis gives clear idea about the age group which behaves homogenous in adoption of mobile wallet.

With respect to subjective norms the age groups 50-59 and $60 \&$ above are significantly different from other age groups 20-29, 30-39 and 40-49

With respect to personal innovativeness the age groups $50-59$ and $60 \&$ above are significantly different from other age groups 20-29, 30-39 and 40-49.

With respect to perceived enjoyment the age group 20-29 is significantly different from other age groups 40-49, 50-59 $\& 60$ and above but there is no significant difference with 30-39

As $p<0.05$, the age group 30-39 is significantly different from other age groups 40-49, 50-59 \& 60 and above but there is no significant difference with 20-29 age group

As $p<0.05$, the age groups 40-49 is significantly different with other age groups

As $p<0.05$, the null hypothesis is not accepted at $5 \%$ level with regard to the age group 50-59. Hence there is significant difference with other groups

As $\mathrm{p}<0.05$, the null hypothesis is not accepted at $5 \%$ level with regard to the age group 60 and above. Hence there is significant difference with other groups, Howcroft et.al. (2002) They observed that that younger consumers are giving more importance to convenience and time saving when they are adopting banking over the internet compared to the older consumers. The current generation of consumers are not giving importance to face-to-face contact when compare to older consumers. The empirical research finding shows that end users feel banking via internet economical and it will not burn their pockets due to unnecessary expenses (Karjaluoto et.al. (2002)). The educational qualification of the respondents does not have any impact on the utilization of banking via telephone or internet (Barnes and Corbitt (2003), Brown et.a1.(2003)).

Chian-Son Yu( 2012) adopted Unified Theory of Acceptance and Use of Technology (UTAUT) to explore factors which influence people's adoption of mobile banking. He found out societal influence, perceived financial cost, performance expectancy and perceived credibility has impact on intention to adopt mobile banking. The behaviour of individual 
towards intention to adopt is influenced by their facilitating conditions. The research concluded that there is a gender significantly moderate between performance expectancy and perceived financial cost. Age moderate between facilitating conditions and perceived self-efficacy on actual adoption behaviour.

\section{CONCLUSION}

The researcher examined the critical factors which influence mobile wallets' adoption among end users and the effect of demographic profile of the respondents such as age and gender. It was concluded that age and gender have significant difference on the intent to adopt mobile wallet. The behaviour of age group 50-59 years and above 60 years are homogenous when compared to other age groups in adoption of mobile wallets. The Government can come forward to reach the above said age groups through awareness campaign, create user friendly mobile apps to encourage the usage of mobile wallets. The initiatives of government on digitalization and demonetization would motivate the consumers to adopt mobile wallet for purchasing of goods \& services. The exponential growth of internet usage \& mobile penetration would help the people to move from cash to digital India in the coming years.

\section{REFERENCES}

1. Agarwal, R., Sarnbamurthy, V. and Stair, R.M. (2000), "Research report: the evolving relationship between general and specific computer self-efficacy: an empirical assessment", Information Systems Research, Vol. 1 1, No. 4, pp. 4 18- 430.

2. Barnes, S.J. and Corbitt, B. (2003), "Mobile banking: concept and potential", International Journal of Mobile Communications, Vol. 1, No. 3, pp. 273-288

3. Brown, I., Cajee, Z., Davies, D. and Stroebel, S. (2003), "Cell phone banking: predictors of adoption in South Africa - an exploratory study", International Journal of Information Management, Vol. 23, No. 5, pp. 38 1-394.

4. Chian-Son $\mathrm{Yu}(2012)$ FACTORS AFFECTING INDIVIDUALS TO ADOPT MOBILE BANKING: EMPIRICAL EVIDENCE FROM THE UTAUT MODEL Journal of Electronic Commerce Research, VOL 13, NO 2, 2012.

5. Cruz, P., L. B. F. Neto, P. Munoz-Gallego, and T. Laukkanen, "Mobile banking rollout in emerging markets: Evidence from Brazil," International Journal of Bank Marketing, Vol. 28, No. 5: 342-371, 2010.

6. Dasgupta, S., R. Paul, and S. Fuloria, "Factors affecting behavioral intentions towards mobile banking usage: Empirical evidence from India,” Romanian Journal of Marketing, Vol. 3, No. 1: 6-28, 2011.

7. Donald L. Amoroso1 and Rémy Magnier-Watanabe (December 2011) Building a Research Model for Mobile Wallet Consumer Adoption: The Case of Mobile Suica in Japan (www.jtaer.com)

8. Furnell, S. (2004), "E-commerce security: A question of trust", Computer Fraud and Security, Vol. 10, pp. 10-14.

9. Garbarino, E. and M. Strahilevitz, "Gender differences in the perceived risk of buying online and the effects of receiving a site recommendation," Journal of Business Research, Vol. 57, No. 7: 768-775, 2004.

10. Howcroft, B., Hamilton, R. and Hewer, P. (2002), "Consumer attitude and the usage and adoption of home-based banking in the United Kingdom", International Journal of Bank Marketing, Vol. 20, No. 3, pp. 1 $11-12$.

11. Jham, V. (2005), "Insights into the customer interactions in the banking industrya qualitative relationship marketing study", Review of Professional Management, Vol. 3, Issue.

12. Johnson, R.D. and Marakas, G.M. (2000), "Research reports: the role of behavior modeling in computer skills acquisition: toward refinement of the model", Information Systems Research, Vol. 1 1, No. 4, pp. 402-4 17

13. Karjaluoto, H., Mattila, M. and Pento, T. (2002), "Electronic banking in Finland: consumer beliefs and reactions to a new delivery channel", Journal of Financial Service Marketing, Vol. 6, No. 4, pp. 346-361.
14. Koening-Lewis, N., A. Palmer, and A. Moll, "Predicting young consumers' take up of mobile banking services," International Journal of Banking Marketing, Vol. 28, No. 5: 410-432, 2010.

15. Khushbu Madan and Rajan Yadav (june 2016) - Behavioural intention to adopt mobile wallet: a developing country perspective (www.emeraldinsight.com/1755-4195.htm)

16. Laukkanen, T., S. Sinkkonen, M. Kivijarvi, and P. Laukkanen, "Innovation resistance among mature consumers," International Journal of Marketing, Vol. 24, No. 7: 419-427, 2007.

17. Nysveen, H., P. E. Pedersen, and H. Thorbjernsen, Explaining intention to use mobile chat services: Moderating effects of gender, The Journal of Consumer Marketing, Vol. 22, No. 4: 247-256, 2005.

18. Parasuraman, A., Zeithaml, V. and Berry, L. (1988), "SERVQUAL: a multipleitem scale for measuring consumer perception of service quality", Journal of Retailing, Vol. 64, No. 1, pp. 12-4.

19. Prof. J. Ramolapremalatha (2016) - Applicability Of Unified Theory Of Acceptance And Use Of Technology In Indian Context - A Review (Indianresearchjournals.Com).

20. Puschel, J., J. A. Mazzon, and J. M. C. Hernandez, "Mobile banking: Proposition of an integrated adoption intention framework," International Journal of Bank Marketing, Vol. 28, No. 5: 389-409, 2010.

21. Riquelme, H. and R. E. Rios, "The moderating effect of gender in the adoption of mobile banking," International Journal of Bank Marketing, Vol. 28, No. 5: 328-341, 2010.

22. Singh, S., Srivastava, V., and R. K. Srivastava, "Customer acceptance of mobile banking: A conceptual framework," SIES Journal of Management, Vol. 7, No. 1: 55-64, 2010.

23. Sripalawat, J., M. Thongmak, and A. Ngramyarn, "M-banking in metropolitan Bangkok and a comparison with other countries," The Journal of Computer Information Systems, Vol. 51, No. 3: 67-76, 2011.

24. Ting-Yu Li, Chien-Ta Bruce Ho - Factors Influencing the Technology Adoption of Mobile Commerce in Taiwan - By Using the Revised UTAUT Model (www.iafor.org).

25. Vinitha K, Vasantha s (July 2017), Factors Influencing Consumer's Intention to Adopt Digital Payment-Conceptual Model, Indian Journal of Public Health Research and Development, 2017, Volume 8, Issue3, Print ISSN: 0976-0245. Online ISSN: 0976-5506, pp 170-175, DOI : 10.5958/0976-5506.2017.00181.4.

26. K. Vinitha \& S.Vasantha ( Nov 2017)Influence Of Demographic Variables On Usage Of E-Payment System, International Journal of Mechanical Engineering and Technology (IJMET) Volume 8, Issue 11, November 2017, pp. 265-276, Article ID: IJMET_08_11_029 ISSN Online: 0976-6359.

27. Vinitha K, Vasantha s (July 2017), Factors Influencing Consumer's Intention to Adopt Digital Payment-Conceptual Model, Indian Journal of Public Health Research and Development, 2017, Volume 8, Issue3, Print ISSN: 0976-0245. Online ISSN: 0976-5506, pp 170-175, DOI : 10.5958/0976-5506.2017.00181.4.

28. Vinitha K,Dr. Vasantha S(August 2017) A Robust move towards Digitalization, Threats and Solutions, International Journal of Current Engineering and Scientific Research, 2017 Volume-4, Issue-8, ISSN (PRINT): 2393-8374, (ONLINE): 2394-0697.

29. V.Poovizhi, P.Kiruthika, E.Madura.m.e, and P.Narmatha. "Blockchain based unforged license." International Journal of Communication and $\begin{array}{lllll}\text { Computer Technologies } 7.2 & \text { (2019), 4-7. Print. }\end{array}$ doi:10.31838/ijccts/07.02.02 